\title{
Scientific Attitude, Attitude to Science and Science Achievement of Senior Secondary School Students in Katsina State, Nigeria
}

\author{
Dr. Olasehinde, Kayode John \\ Department of Science Education, Faculty of Science and Education, \\ Federal University, Dutsin-Ma, Katsina State \\ olasehindekayodej@gmail.com, kolasehinde@fudutsinma.edu.ng \\ Dr. Olatoye, Rafiu Ademola \\ Department of Science Education, Faculty of Science and Education, \\ Federal University, Dutsin-Ma, Katsina State \\ kingdemola@yahoo.com, rolatoye@fudutsinma.edu.ng
}

\section{Doi:10.5901/jesr.2014.v4n1p445}

\begin{abstract}
The study examined scientific attitude, attitude to science and science achievement of senior secondary school students in Katsina State, Nigeria. The descriptive survey research design was used for the study. Random sampling technique was employed to select 204 senior secondary school students from the three geopolitical zones of the state. Three instruments were used to collect data viz: (1) Scientific Attitude Questionnaire (SAQ); (2) Attitude to Science Questionnaire (ASQ) and Science Achievement Test (SAT). Data were analysed using multiple regression, linear regression, Pearson ProductMomement Correlation and t-test. The findings show that attitude to science and scientific attitude together account for $0.7 \%$ of total variance in science achievement $(R 2=0.007, p>0.05)$; scientific attitude accounts for $0.06 \%$ of total variance in science achievement ( $R 2=006, p>0.05)$; attitude toward science accounts for $0.01 \%$ of the total variance in science achievement (R2 $=.001, p>0.05)$. The results further show that there is a significant positive relationship between scientific attitude and attitude to science $(r=+0.581, p<0.05)$; relationship between scientific attitude and science achievement was positive but not significant $(r=+0.077, p>0.05)$; relationship between attitude to science and science achievement was also positive but not significant ( $r$ $=+0.024, p>0.05$ ). There is no significant difference between male and female students in scientific attitude, attitude to science and science achievement ( $t=-0.375,0.597$ and $-0.678, p>0.05$ respectively). It was recommended among others that researchers should look more inwards to detect what factors hinder science achievement in schools.
\end{abstract}

Keywords: Scientific attitude, attitude to science, students, science achievement

\section{Introduction}

The level of development of any country is largely based on the level scientific knowledge. Progress in science depends upon continuous scientific investigations. Many researchers have reported that, well-organized and well-equipped laboratories are essential in science teaching. It has also been shown that one of the most important factors in science teaching is the attitude which determines behaviour (Amjad \& Muhammad, 2012). Also the importance of science is clear to most people; however the majority of the population is illiterate in science (Crocker, 1997). One of the goals of the science teaching is to encourage students to have positive attitude towards science for positive effects on students' learning (Northwest Region Education Laboratory (NREL), 2002).

According to Karlinger, (1970) attitude is a psychological construct, or latent variable, inferred from observable responses to stimuli which are assumed to mediate consistency and coherence among those responses. He went further to explain that attitude is related to thinking, feeling, perceiving and behaving toward a cognitive object. Anastasi (1969) noted that attitude is a tendency to react favourably or unfavourably towards a designated class of stimuli. He further remarked that it was synonymous with opinion. The attempted differentiation between attitude and opinion was, "neither consistent, nor logically definable". Thurstone (1928) who was the first to undertake measurement of attitude defined it as, "The degree of positive or negative effect associated with some psychological object". From the standpoint of these characteristics, attitude becomes psychologically inseparable from a number of other concepts which can be subsumed 
under the same construct. These include interests, appreciation, likes, dislikes, opinions, values, ideals, social distance, character traits and loyalties. Attitudes have emotional content and vary in intensity and generality according to the range of objects or situations over which they apply. Mostly attitude learnt are difficult to distinguish from such affective attributes of personality such as interest, appreciation, likes, opinion, values, ideals and character traits (Baumil \& Beger, 1965).

Attitude does not only include the negative attitude such a prejudices biases and dislikes, but also positive attitudes are sometimes called sentiment, which include our attachment and loyalties to person, objects and ideas (George, 2000). Attitude thus seems like a system of ideas with an emotional core or content. An individual possesses his or her life, he or she acquires not only skills and knowledge, but also definite attitudes, point of views and feelings about his or her experiences. These definite attitudes, point of views and feelings are developed not only due to what kind of experiences the individual passes though, but also how these experiences came across.

Tendency to react favourably or unfavourable toward designated class of stimuli is attitude. If this reaction is according to the ethics of science, then it is scientific attitude. The scientific attitude investigates certain scientific acts or thoughts. Scientific attitude is the ability to react consistently, rationally and objectively in certain ways to a novel or problematic situation. It is the ability to do things in a way that rely on proven principles rather than unverified principles. A person with good scientific attitude is free from superstition, unverified assumptions and many times from popular opinion that has no empirical basis (Olatoye, 2002; Olatoye \& Aderogba, 2012; Klopfer, 1995). A person with scientific attitude is not necessarily a scientist but he or she consciously or unconsciously thinks, acts and demonstrates traits that are common to scientists.

The habit or thought associated with scientific thinking deserves more careful consideration. Munby (1983) defined scientific attitude as the thinking pattern, characteristic of scientists. To be scientific mean that one has such attitudes as curiosity, rationality, willingness to suspend judgment, open-mindedness, critical-mindedness, objectivity, honesty and humility. Scientific attitude regulate behaviour that is directed towards or away from some object or situation, or group of objects or situations.

Attitude towards science implies a general positive or negative feeling about science; whether a person likes or dislikes science (Crawley \& Koballa, 1994). Many factors could contribute to students' attitude towards studying science. Slee (1964) indicated that students' attitude and interests could play substantial role among pupils studying science. Several studies including Simpson and Oliver (1990), Wilson, (1983), Soyibo, (1985) reported that students' positive attitudes to science correlate highly with their science achievement. Again, Balogun (1975) reported that, in general, the attitudes of Nigerian students towards the basic sciences tend to decrease in the order, Biology, Chemistry, Physics and Mathematics.

Attitude towards science is closely related to achievement in science (George, 2000). A significant relationship was found with a mean correlation ranging from 0.16 to 0.70 between students' attitude toward science and their achievement (Wilson, 1983; Marsh, 1992). Bloom (1976) reported that attitude accounted for up to $25 \%$ of the variability in students' achievement scores. These studies showed that the relationship between students' attitude and their achievement is not simple but causation in nature.

One of the concerns of teacher education is to bring about a positive change in attitude. Teacher training is concerned with desirable change in student-teachers' attitude toward himself/herself and his/her pupils (Abdul, 1982). Attitude has an effect upon students' selection of different subjects and also on their interest and achievement in the scientific knowledge (Adesoji, 2008). Generally, attitudes are considered as the degree of positive or negative feelings towards an object, course or event. Positive or favourable attitude facilitates the learning of subjects while a negative attitude results in poor learning because achievement determines behaviour.

In spite of all efforts by science educators, science still remains a dreadful subject by learners in the schools. This is evidenced by the low enrolment for science in secondary schools (Olasehinde, 2008), as well as underachievement at the secondary school certificate level examinations (Olagunju, 1998). The root of the problem probably lies in poor science teaching at the foundational primary school level. The traditional talk and chalk method, which is the most widely used in schools, is wasteful and unproductive, particularly with slow and average learners (Nneji, 1997). It has also been shown to be ineffective in engaging learner's positive attitude, in developing the conceptual understanding of the subject matter (Stofflet \& Stoddart, 1994). This is probably why the problem of poor achievement in science subjects still persists.

Gender issues have been a major focus in science education. Research has shown that boys have more positive attitude than the girls, as well as higher achievement scores (Rosier \& Barkis, 1990). Over twice as many boys have future interest in science than girls (Catasambis, 1995). The same results of females having a less positive attitude toward science than do males are found in many studies (George, 2000). Also, Raimi and Adeoye's (2002) findings 
revealed that there is a significant difference between males and females in term of their attitude towards integrated science in favour of male. Perhaps, this has been the reasons for males' better performance in integrated science cognitive achievement. This finding corroborates earlier findings of Raimi and Oduwaye (1997) which observed similar difference between males and females. This finding appears to confirm the fear of researchers such as Oyedeji (1996) that in African setting science seems to wear a masculine label.

Erinosho (2008) noted that Nigerian data indicates that girls formed 32\% of arts students, $28 \%$ social sciences students, and a mere 17\% of the natural sciences in the Senior Secondary Certificate Examination (SSCE) in 1999-2004. Data on female participation in university education also show the disparity across disciplines: for every female that is enrolled for courses in 2000 to 2004, eight males were in engineering three in environmental sciences, and two in the natural sciences. Females constitute a paltry $10.2 \%$ even at the level of academic staff. For every female academic staff in different disciplines, there were twenty-six males in engineering, fourteen in environmental sciences, and seven in the basic sciences (Erinosho, 2008).

The importance of scientific attitude and attitude to science cannot be overemphasized in enhancing students' achievement in science. This study therefore sought to investigate how two independent variables (scientific attitude and attitude to science) influence students' achievement in science.

\section{Hypotheses}

The following hypotheses were tested at 0.05 level of significant.

1. Scientific attitude, attitude to science taken together will not significantly influence students' achievement in science

2. Scientific attitude alone will not significantly influence students' achievement in science

3. Student attitude to science alone will not significantly influence achievement in science

4. There is no significant relationship between each of the independent variables (scientific attitude and attitude to science) and science achievement

5. There is no significant difference between male and female students'

i. Scientific attitude;

ii. Attitude to Science and

iii. Science achievement.

\section{Methodology}

\subsection{Research Design}

The descriptive survey research design was employed to carry out this study. The aim of the researchers was to record, analyze and interpret the existing conditions or variables. The research is non-experimental and therefore variables were not manipulated. This makes descriptive survey research design suitable for this study. This design also accommodates generalization of findings of the study upon the target population from which only a representative sample was actually studied.

\subsection{Target Population and Sample}

The target population for the study comprised all the students in Senior Secondary School (SSS) Two in Katsina State, Nigeria. Katsina State is one of the 36 states in Nigeria. It has cultural and educational similarities with six other states in the North-West geo-political zone of Nigeria. Katsina state was divided into three zones namely: Daura, Funtua and Katsina. This is the existing political divisions in the state. A random sample of one Local Government Area (LGA) was selected from each zone. From each Local Government Area, a random sample of two public and two private schools were selected from each LGA and a total of 12 schools (6 public and 6 private schools) were selected from the entire state. From each school, twenty SSS 2 Science Students were randomly selected to participate in the study. Though the expected sample size was 240 , however only 204 students fully participated in the study. The average age of the students is 17 years. 


\subsection{Instrumentation}

Three instruments were used to collect data for this study. They are:

i. Scientific Attitude Questionnaire (SAQ)

ii. Attitude to Science Questionnaire (ASQ)

iii. Science Achievement Test (SAT)

SAQ and ASQ were designed by the researchers. Each of these questionnaires has 12 items with a four-point Likert-type scale of 'Strongly Agree', 'Agree', 'Disagree' and 'Strongly Disagree'. The respondents were asked to indicate their feelings to each statement/item by ticking any of the four possible responses on the scale. The items on the instruments cover different aspects of the variables being considered. Respondents were asked to indicate their gender and type of school on the questionnaires.

SAT is a 30-item achievement test that covers the three core subjects in science namely biology, chemistry and physics. Ten items were drawn from each of these subject areas.

Examples of items on SAQ:

1. I always like to find out details of what happen around me

2. I don't allow my belief to affect me in passing judgement about issues.

3. I don't give immediate conclusion on issue until I find out details.

Examples of items on ASQ:

1. I like science.

2. Science makes the world a better place.

3. I will like to take up a course in science-related field in future.

Examples of items on SAT:

1. A group of closely related organisms capable of interbreeding to produce fertile offspring are known as members of (a) kingdom (b) class (c) family (d) species

2. How many orbital is in the d-sub shell? (a) 1 (b) 3 (c) 5 (d) 7 .

3. The derived unit of pressure can be expressed as: (a) Kgms ${ }^{-2}$ (b) $\mathrm{Kgm}^{-s^{-2}}(\mathrm{c}) \mathrm{Kgm}^{-2} \mathrm{~s}^{-2}(\mathrm{~d}) \mathrm{Kgm}^{-1} \mathrm{~s}^{2}$

The content validity of the two questionnaires and the achievement tests was ensured through experts' suggestions and guidance. Experts in questionnaire construction helped in critiquing the items. All the achievement items were selected from already standardised items produced by the West African Examinations Council. The items selected were only on the topics covered in all the schools selected for the study. The test retest reliability yielded $0.73,0.79$ and 0.76 coefficients for SAQ, ASQ and SAT respectively.

\subsection{Method of Data Analysis}

The data collected were analysed using Statistical Package for Social Sciences (SPSS) version 17.0. Hypothesis 1 was answered using multiple regression, hypotheses 2 and 3 were answered using linear regression, hypothesis 4 was answered using Pearson product-moment correlation while hypothesis 5 was answered using t-test.

\section{Results}

4.1 Hypothesis 1: Scientific attitude, attitude to science taken together will not significantly influence student achievement in science

Table 1: Attitude to Science and Scientific Attitude as Predictors of Science Achievement

\begin{tabular}{|l}
\begin{tabular}{|c|c|c|c|c|c|c|}
\hline $\mathrm{R}=0.081$ Adjusted $\mathrm{R}$ square $=0.003$ \\
$\mathrm{R} 2=0.007$ Standard Error $=3.160$ \\
\hline & Sum of Square & $\mathrm{df}$ & Mean Square & $\mathrm{F}$ & Sig & Remark \\
\hline Regression & 13.149 & 2 & 6.574 & & & \\
Residual & 2006.787 & 201 & 9.984 & .658 & .519 & NS \\
Total & 2019.936 & 203 & & & & \\
\hline
\end{tabular}
\end{tabular}

NS=Not significant $(p>0.05)$

In table 1, the two independent variables (attitude toward science and scientific attitude) account for $0.7 \%$ of the total 
variance in science achievement $\left(R^{2}=0.007, p>0.05\right)$. This percentage is low and not significant. Thus, the two independent variables do not significantly influence students' science achievement. This also implies that there are other factors not considered in this study that can significantly influence student science achievement.

\subsection{Hypothesis 2: Scientific attitude will not significantly influence student achievement in science.}

Table 2: Scientific Attitude as a Predictor of Science Achievement

\begin{tabular}{|c|c|c|c|c|c|c|}
\hline \multicolumn{7}{|c|}{$\begin{array}{l}R=0.077 \text { Adjusted } R \text { square }=0.001 \\
R^{2}=0.006 \text { Standard Error }=3.15291\end{array}$} \\
\hline & Sum of Square & Df & Mean Square & $F$ & Sig & Remark \\
\hline $\begin{array}{c}\text { Regression } \\
\text { Residual } \\
\text { Total }\end{array}$ & $\begin{array}{c}11.881 \\
2008.055 \\
2019.936\end{array}$ & $\begin{array}{c}1 \\
202 \\
203\end{array}$ & $\begin{array}{c}11.881 \\
9.941\end{array}$ & 1.195 & .276 & NS \\
\hline
\end{tabular}

NS=Not significant $(p>0.05)$

Table shows that scientific attitude alone accounts for $0.6 \%$ of the total variance in science achievement $\left(R^{2}=0.006\right.$, $\mathrm{p}>0.05$ ). This percentage is not significant. Thus, in order to enhance science achievement, raising students' scientific attitude is not necessarily the solution. Other factors not considered for in this study will probably account for student achievement in science.

\subsection{Hypothesis 3: Attitude towards science will not significantly influence student achievement in science.}

Table 3: Attitude towards as a Predictor of Science Achievement

\begin{tabular}{|c|c|c|c|c|c|c|}
\hline \multicolumn{7}{|c|}{$\begin{array}{l}R=0.024 \text { Adjusted } R \text { square }=0.004 \\
R^{2}=0.001 \text { Standard Error }=3.16130\end{array}$} \\
\hline & Sum of Square & $d f$ & Mean Square & $\mathrm{F}$ & Sig & Remark \\
\hline Regression & $\begin{array}{c}1.179 \\
2018757\end{array}$ & 1 & $\begin{array}{l}1.179 \\
9.994\end{array}$ & & & \\
\hline $\begin{array}{l}\text { Residual } \\
\text { Total }\end{array}$ & $\begin{array}{l}2018.757 \\
2019.936\end{array}$ & $\begin{array}{l}202 \\
203\end{array}$ & 9.994 & 118 & .732 & NS \\
\hline
\end{tabular}

NS=Not significant $(p>0.05)$

Tale 3 shows that attitude towards science alone accounts for $0.1 \%$ of total variance in science achievement $\left(R^{2}=0.001\right.$, $p>0.05$ ). The percentage is not significant. Increasing the attitude towards science is may not necessarily lead to increase in students' science achievement. Other factors may be looked into in an attempt to improve students' science achievement.

4.4 Hypothesis 4: There is no significant relationship between each of the independent variables (scientific attitude and attitude to science) and science achievement

Table 4: Relationship between each of the Independent Variables (Scientific Attitude and Attitude towards Science) and Science Achievement.

\begin{tabular}{|l|c|c|c|}
\hline & Scientific Attitude & Attitude to Science & Science Achievement \\
\hline Scientific Attitude Pearson Correlation & 1 & $.581^{\star *}$ & .077 \\
Sig.(2-tailed) & & .000 & .276 \\
N & 204 & 204 & 204 \\
\hline Attitude to Science Correlation & $.581^{\star \star}$ & 1 & .024 \\
Sig.(2-tailed) & .000 & 204 & .732 \\
N & 204 & .077 & 204 \\
\hline Science Achievement Pearson Correlation & .077 & .024 & 1 \\
Sig.(2-tailed) & .276 & .732 & 204 \\
N & 204 & 204 & \\
\hline
\end{tabular}

${ }^{*}$ Correlation is significant at the 0.05 level (2-tailed). 
In table 4, there is a significant positive relationship between students' scientific attitude and attitude to science ( $r=$ $+0.581, p<0.05$ ). The higher the students' attitude to science, the higher their scientific attitude and the lower the students' attitude to science, the lower the scientific attitude. However there is low, though positive but not significant relationship between students' scientific attitude and science achievement $(r=+0.077, p>0.05)$. Likewise, there is low, though positive, not significant relationship between student scientific attitude and science achievement $(r=+0.024$, $p>0.05$ ). Though it can be said that when students' scientific attitude or attitude to science increases, science achievement also increases ( since the relationship is positive), however the relationship between them is not significant.

\subsection{Hypothesis 5: There is no significant difference between male and female students'}
i. Scientific Attitude;
ii. Attitude to Science and
iii. Science Achievement.

Table 5: Comparison of Male and Female Scientific Attitude, Attitude towards Science and Science Achievement

\begin{tabular}{|c|c|c|c|c|c|c|c|c|c|}
\hline & Gender & $\mathrm{N}$ & Mean & Std Dev & Std Error & $\mathrm{df}$ & $t$ & $P$ & Remark \\
\hline Scientific Attitude & $\begin{array}{c}\text { Male } \\
\text { Female }\end{array}$ & $\begin{array}{c}119 \\
85\end{array}$ & $\begin{array}{l}38.1849 \\
38.4588\end{array}$ & $\begin{array}{l}4.53978 \\
5.54323\end{array}$ & $\begin{array}{l}.41616 \\
.60125\end{array}$ & 202 & -.375 & .708 & NS \\
\hline Attitude to Science & $\begin{array}{c}\text { Male } \\
\text { Female }\end{array}$ & $\begin{array}{c}119 \\
85\end{array}$ & $\begin{array}{l}42.1849 \\
41.7647\end{array}$ & $\begin{array}{l}4.50417 \\
5.53054\end{array}$ & $\begin{array}{l}.41290 \\
.59987\end{array}$ & 202 & .597 & .551 & NS \\
\hline Science Achievement & $\begin{array}{c}\text { Male } \\
\text { Female }\end{array}$ & $\begin{array}{c}119 \\
85\end{array}$ & $\begin{array}{l}7.0840 \\
7.3882\end{array}$ & $\begin{array}{l}3.05203 \\
3.30258\end{array}$ & $\begin{array}{l}.27978 \\
.35821\end{array}$ & 202 & -.678 & .498 & NS \\
\hline
\end{tabular}

Table 5 shows that there is no significant difference between male and female students in scientific attitude, attitude to science and science achievement ( $t=-.375, .597$ and -.678 respectively, $p>0.05)$. Male and female students have the same level of scientific attitude, attitude to science and science achievement. In each of the variables, the difference between male and female mean scores is not significant.

\section{Discussion}

The study reveals that scientific attitude and attitude to science combined together to account for just 0.7 percent of variance in science achievement. This shows that the non-performance of students in science achievement is not because they do not have favourable scientific attitude or attitude to science. It shows that there are other factors that hinder science achievement of the students especially within the target population. Thus the position of Slee (1964); Simpson (1978); Wilson (1983); Soyibo (1985) that positive attitude to science subjects improve science achievement is further challenged. It is therefore not necessary for teachers to dissipate his/ her time to make the students develop scientific attitude or attitude to science in attempt to improve science achievement of the students.

Scientific attitude alone has total variance of $0.6 \%$ on science achievement. This shows that $99.4 \%$ of what can improve science achievement will be from other variables. It is obvious that the teachers, curriculum planners, parents and all other stakeholders in science education need to work harder to identify factors causing the low science achievement among the students.

Attitude to science alone also has a total variance of $0.1 \%$ on science achievement. it denotes that positive attitude to science does not imply that the students will have high science achievement. This implies that, like scientific attitude earlier discussed other variables will account for a total variance of $99.9 \%$. It is pertinent to note that the widely belief submission that attitude to science greatly predict achievement in science is unfounded in this study.

There is a positive significant relationship between scientific attitude and attitude to science. This shows that the more the scientific attitude of the student the more the attitude to science. Also scientific attitude, attitude to science have positive but not significant relationship with science achievement.

There was no significant difference between the male and female students in scientific attitude, attitude to science and science achievement. This implies that no serious gender disparity among the male and female students. The results of male and female students also reveal very low performance of students in science. The maximum obtainable score in the Science Achievement test was 30, yet the mean scores for male and female students are below 8 . The percentage 
mean is less than $25 \%$. This is very poor and not encouraging.

Olatoye (2002) opined that science education lays foundation for work in science-related fields by acquainting learners with certain knowledge and skills. With the very low achievement students in science reported in the study, there is need to look outside the factors considered in this study. According to Olatoye ((2009a, 2009b) factors such as test anxiety, motivation for examinations, study habit and self-concept have significant influence on students' achievement in science.

\section{Conclusion}

In conclusion the study reveals that scientific attitude and attitude to science do not significantly predict science achievement. Each of scientific attitude and attitude to science has positive but no significant relationship with science achievement. The comparison of mean scores by gender in scientific attitude, attitude to science and achievement in science were not significant. The findings in the study give cause for concern. This is because two important independent variables (scientific attitude and attitude towards science) that many scholars have reported to significantly predict science achievement failed to do so in this study. The findings of this is not trying to disprove these scholars but rather drawing attention to the fact the important factors that can really raise science achievement in the target population are not these two independent variables. It is now left for researchers to propose other achievement for another empirical investigation. The low performance of students in science in this study is another major concern.

\section{Recommendations}

Based on this finding, it becomes imperative to give the following recommendations: Researchers should look more inwards for what could hinder science achievement in schools because scientific attitude, attitude to science have been discovered not to account for what can seriously affect science achievement negatively.

Male and female students should be encouraged to participate more in science. Researchers should intensify efforts to detect what variables will improve science achievement among secondary school students. Also stakeholders in science education should provide required fund to researchers to enable them find out what variables will enhance students' science achievement.

\section{References}

Abdul, R. (1982). Measurement of the Development of Attitude Toward Teaching Profession Among the Student Teachers in the Two Year Programme of the IER University. Punjab 32.

Amjad I. P. \& Muhammad F.(2012). Measurement of Scientific Attitude of Secondary School Students in Pakistan. Academic Research International 2 (2), 379-392.

Anatasi, A. (1969). Psychological Testing. 479.

Adesoji, F. A. (2008).Managing Students' Attitude Towards Science through Problem-Solving Instructional Strategy. Anthropologist, 10(1), 21-24.

Balogun, T. A.. (1975). Interest in Science and Technology in Nigeria. Journal of Science Teacher Association in Nigeria. 23 (1\&2), $92-$ 99.

Baumil, H. \& Beger, J. J. (1965). Attempt to Measure Scientific Attitude. Science Education, 3 (49), 268.

Bloom, S. B. (1976). Human Characteristics of School Learning. New York Mc Craw Hill.

Catasambis, S . (1995). Gender, Race, Ethnicity and Science Education in Middle Grades. Journal of Researcher in Science Teaching 32 (3), 243-257.

Crawley, F.E., \& Koballa, T.R. (1994). Attitude Research in Science Education: Contemporary Model and Methods. Science Education, 78, 35-55.

Crocker, M. (1997). A Summary of the Shaping the Future Report Focus on Microbiology. Newsletter. Spring 5-8.

Defiana, A. (1995). Environment Awareness: Relating Current Issues to Biology. The Science Teachers. 21, 31-39.

Erinosho, S. Y. (2008). Teaching in Science in Senior Secondary Schools: A Methodology Handbook. Lagos: African Cultural Institute.

George, R. (2000). Measuring Change in Students Attitude towards Science Overtime. Journal of Science Education and Technology, 9 (3), 213-225.

Karlinger, F. N.(1970). Foundation of Behavioural Research. Northridge. 484

Klopfer, L. E. (1995). "Scientific Literacy". In: T Husen and T.N. Postlethwaite (Eds). The International Encyclopedia of Education, Pergamon Press: Oxford, UK.

Marsh, H. W. (1992). Content Specificity in Relation between Academic Achievement and Academic Self Concepts. Journal of Education Psychology, 84: 35-42. 
Munby, H. (1983). Thirty Studies Involving the Scientific Attitude Inventory. What Confidence can we in this Instrument? Journal of Research in Science Teaching, 20 (2), 141-162.

Nneji, I. M. 1997. Evaluation of Population and Family Life Education at Various Levels. An Evaluation of POP/FLE Contents in Primary Science Curriculum. 1,108

Northwest Regional Educational Laboratory (NREL) (2002). It's just good Teaching Mathematics and Science Classrooms Building a Community of Learns. Retrieved April 10, 2013 from http//:wwwnirrel.org

Olagunju, A.M. (1998) The Impact of Two Curriculum Packages in Environmental Education in Biology on Learners Performance, Problem Solving Ability and Environmental Attitude. Unpublished Ph.D. Thesis Teacher Education Department, University of Ibadan

Olasehinde, K. J. (2008). Effect of School of Location on Student Cognitive Achievement in Population Education Concepts in biology. Sahel Analyst. Journal of the Faculty of of Social and Management Sciences Science. 10 (1), 43-48.

Olatoye, R A. (2009a). Study Habit, Self-Concept and Science Achievement of Public and Private Junior Secondary School Students in Ogun State, Nigeria. African Research Review, 13, (4)

Olatoye, R. A. (2009b) Students' Test Anxiety. Motivation for examinations and science achievement in junior secondary schools in ogun state, Nigeria. International Journal of Psychology and Counselling,1 (10), 194-198.

Olatoye, R. A. \& Aderogba, A. A. (2012). Harnessing the Power of Emotional Intelligence, Scientific Literacy and Problem-Solving Skills for Successful Living. Pacific Journal of Science and Technology, 13 (1), 403- 417.

Olatoye, R.A, (2002). A Causal Model of School Factors as Determinants of Science Achievement in Lagos State Secondary Schools. An Unpublished PhD Thesis, University of Ibadan, Nigeria.

Oyedeji, A.O. (1996). Assessing Gender Factors in Some Science and Mathematics Tests in Nigeria. Journal of Education Research 8 (1), 45-53.

Raimi, S. A. \& Adeoye, F. A. (2002).Gender Differences among College Students as Determinant of Performance in Integrated Science. African Journal of Educational Research, 8 (1\&2), 41-49.

Raimi, S. A. \& Oduwaye, J. O. M. (1997). College Students 'Attitude towards Integrated Science as Predictor of Achievement in the Subject. Journal of Science Education 2 (2), 10-17.

Rosier, M. J. \& Barkis, D. K. (1990). The Scientific Literacy of Australian Students: Science Achievement of Students in Australian Primary and lower Secondary. Australian Council for Educational Research. Research Monograph. 39 Hawthorn, Victoria:

Simpson, R. D \& Oliver J S (1990). A Summary of Major Influence on Attitude Towards Achievement in Science Among Adolescent Students. Science Education 74 (1), 1-18

Slee, F.W. (1964). A Factorial Study of the Study Attributes of Secondary Modern Children to School Subjects. Unpublished M.Ed Thesis Manchester University. In: Adesoji SF. A. .Managing Students Attitude towards Science through Problem-Solving Instructional Strategy. Anthropologist, 10 (1), 21-24.

Sofflent, R \& Stoddart, T. (1994). The Accommodation of Conceptual Changes Constructs to Teacher Education. Journal of Research in Science Teaching 31 (8), $787-810$.

Soyibo, K. A. (1985). Comparison of Selected Lagos Students Attitude to Performance on a biology test. In: Adesoji (2008). Managing Students Attitude Towards Science Through Problem Solving Instructional Strategy, Anthropologist 10 (1), 21-24.

Thurstone, L. L. (1928). Attitude can be Measured. American Journal of sociology 33,529-554. In: Wikipedia Encyclopaedia. Thurstone Scale. http://en.wikipedia.org/w/Attitude_(psychology) Retrieved April, 8 2013.

Wilson, V. L. (1983). A Meta Analysis of the Relationship Between Science and Achievement and Science Attitude Kindergarten through College. Journal of Research in Science Teaching 20 (9), 839-855

Yoloye, T. W. (1999). Assessing the Attitude, Study Habit and Performance in Science of Some Students After a Counseling Programme. In: Obemeata, J.O., Ayodele, S.O. and Araromi, M.A Eds. Evaluation in Africa in Honour of E.A Yoloye. 